\title{
Counseling with Tooth Brushing Demonstration Method as an Effort to Improve Tooth Brushing Skills and the Status of Dental and Oral Hygiene in Early Childhood at School
}

\author{
Ngatemi $^{1}$, Tedi Purnama ${ }^{1}$ \\ ${ }^{1}$ Assistant Professor, Department of Dental Health, Health Polytechnic of Jakarta I, Indonesia
}

\begin{abstract}
Dental health problems suffered by many people in Indonesia is dental caries. Poor dental and oral hygiene is one of the factors causing dental caries or oral and dental health problems. Teaching oral health with demonstration method can improve tooth brushing skills and reduce oral and dental hygiene in early childhood. This study aims to the effectiveness of counseling with brushing demonstration method as an effort to improve tooth brushing skills and the status of dental hygiene in early childhood in school. Method: this study used a quasy experiment with a pretest and posttest with one group design. This research was conducted at Kindergarten Dharma Putra Nusantara 86 Cilandak District, South Jakarta City. Independent variable: counseling by demonstration method and the dependent variable: brushing skills and the status of early childhood dental and oral hygiene. Data were tested using Wilcoxon. Results: counseling with a tooth brushing demonstration method was effective in improving brushing skills $(\mathrm{p}<0.001)$ and effective in improving the status of early childhood dental and oral hygiene $(p<0.001)$. Conclusion: Counseling with the demonstration method of tooth brushing is effective as an effort to improve tooth brushing skills and the status of dental and oral hygiene in early childhood at school.
\end{abstract}

Keywords: Tooth brushing demonstration method,brushing skills, the status of dental and oral hygiene.

\section{Introduction}

The goal of health development is the creation of Indonesian people who live and behave in a healthy environment and are able to reach quality health services. On the other hand, health services provided throughout Indonesia must be carried out fairly, evenly and optimally. Health development is directed at increasing the awareness, willingness and ability to live a healthy life for everyone so that the highest degree of public health can be realized. ${ }^{1,2}$ Healthteeth are an integral part of general health. Besides teeth is one of the digestive organs that plays an important role in the process of

\section{Corresponding Author:}

Tedi Purnama

Department of Dental Health, Health Polytechnic of Jakarta I, Wijaya Kusuma Raya Street, No. 47, Jakarta, Indonesia

e-mail: tedypurnama23@yahoo.com masticating food. Dental and oral hygiene maintenance is one of the efforts to improve health so as to prevent various oral diseases. ${ }^{3}$

Dental and oral health problems can occur in adults and children. However, children are more vulnerable to these problems, especially post-school children. This is evidenced by the results of the 2018 Basic Health Research reports that $93 \%$ of early childhood aged 5-6 years experience dental health problems; with a national deft value of 8.43 , it means that the average number of tooth decay is 8 to 9 teeth per child. The high rate of dental and mouth disease is currently very much influenced by several factors, one of which is the behavioral factor of the people who are not yet aware of the importance of maintaining oral health. It is seen that the brushing behavior of the population aged $\geq 3$ years by $2.8 \%$ behaves to brush teeth properly. ${ }^{4,5}$

Dental plaque is a soft, colorless sediment and contains a variety of bacteria that are firmly attached to the tooth surface. Plaque cannot be cleaned by gargling, 
water spray or air, but plaque can only be cleaned mechanically. Until now the most effective mechanical way to clean plaque is by brushing teeth. ${ }^{6}$

The ability to brush your teeth properly and correctly is a fairly important factor for dental and oral health care. Rubbing teeth namely the simple action of removing plaque and food scraps with a brush and toothpaste, because plaque and food scraps are the main cause of dental caries. ${ }^{7,8}$

Poor dental and oral hygiene is one of the factors causing dental caries or oral and dental health problems. Poor oral hygiene causes plaque accumulation which contains various kinds of bacteria including the bacterium Streptococcus mutans as the main cause of caries. Zulfikri research (2017) shows the status of dental and oral hygiene of children with moderate criteria totaling 31 people $(51.7 \%)$, with poor criteria 29 people $(48.3 \%)$, and very good criteria totaling $(0 \%)$ and good criteria $(0 \%)$ because there are no students who have very good criteria and good criteria. ${ }^{9,}, 10$

Efforts to maintain oral health and the development of dental health, especially in school children, need special attention because at this age children are undergoing a process of growth and development that will affect the development of dental health in later adulthood. Through the counseling program it is expected that the target can increase the knowledge criteria and make aware of the importance of maintaining oral health and be able to actively participate in improving self-care efforts. ${ }^{11}$

The choice of demonstration method in oral and dental health education supports the improvement of children's understanding, by directly practicing the right way to brush their teeth. Demonstration method is one of the challenging method for children because it can satisfy a child's great curiosity about something that is learned and wants to be known. This demonstration method is also right for children because it matches the concrete style and way of thinking and enhances more critical thinking. Ilyas research (2012) shows that there is an effect of dental and oral health counseling with demonstration method on decreasing plaque scores in children. ${ }^{6,12}$

Based on background above author interested in conducting research with the title "Counseling with brushing demonstration method as an effort to improve tooth brushing skills and dental hygiene status in early childhood at school"

\section{Research Methodology}

The method used in this research is quasy experiment with pre and post-test design with one group design. The study was conducted at Kindergarten Dharma Putra Nusantara 86 Cilandak District, South Jakarta City during February 2020. The research sample was taken with a total sampling technique, as many as 40 students. The independent variable in this study was demonstration of tooth brushing demonstration and the dependent variable was the ability to brush teeth and the exclusion status of preschool children.

Data collection on tooth brushing skills was measured by brushing teeth, validity and reliability tests had been carried out by the same researchers who examined tooth brushing skills. Dental hygiene status was measured by a standard dental hygiene examination that is the PHP-M index. ${ }^{13}$ Stages of activities are as follows: pre-test by observing brushing and checking the status of children's dental hygiene, then intervening for 5 days in the form of counseling with a demonstration method of brushing teeth and practice brushing teeth at school every day and finally post-test by observing brushing teeth and check the child's dental hygiene status to see the changes. The research data uses ratio scales and statistical tests, because the data are not normal using Wilcoxon.

\section{Result}

Table 1. The mean value of tooth brushing skills and dental and oral hygiene status

\begin{tabular}{|c|l|c|c|c|}
\hline No. & Variable & Mean & SD & Min-Max \\
\hline \multirow{4}{*}{1} & \multicolumn{4}{|c|}{ Tooth brushing skills } \\
\cline { 2 - 5 } & Pre-test & 5.67 & 1.298 & $4-9$ \\
\cline { 2 - 5 } & Post-test & 8.87 & 0.596 & $8-10$ \\
\hline \multirow{4}{*}{2} & Dental and oral hygiene status (PHP-M) \\
\cline { 2 - 5 } & Pre-test & 31.95 & 9,686 & $16-59$ \\
\cline { 2 - 5 } & Post-test & 19.45 & 7,980 & $10-45$ \\
\hline
\end{tabular}

Table 1. Shows the average value of children's tooth brushing skills increased from 5.67 to 8.87 and the value of dental and oral hygiene status decreased from 31.95 to 19.45

Table 2. Test data normality

\begin{tabular}{|c|l|c|c|}
\hline No. & Variable & Pre-test & Post-test \\
\hline 1 & Tooth brushing skills & 0.002 & 0,000 \\
\hline 2 & Dental and oral hygiene status & 0,000 & 0,000 \\
\hline
\end{tabular}

*Kolmogorov-Smirnov 
Based on table 2 shows the normality of tooth brushing skills and dental and oral hygiene status p-value $<0.05$, meaning that the data is not normally distributed so non-parametric tests.

\section{Table 3. Test the effectiveness of tooth brushing skills and dental and oral hygiene status before and after counseling interventions with the brushing demonstration method}

\begin{tabular}{|l|l|c|c|}
\hline \multicolumn{2}{|l|}{ Variable } & Mean+SD & P-value \\
\hline \multirow{2}{*}{ Tooth brushing skills } & Pre-test & $5.67+1,298$ & \multirow{2}{*}{0.001} \\
\cline { 2 - 3 } & Post-test & $8.87+0.596$ & \\
\hline \multirow{2}{*}{$\begin{array}{l}\text { Dental and oral hygiene } \\
\text { status }\end{array}$} & Pre-test & $31.95+9,686$ & \multirow{2}{*}{0.001} \\
\cline { 2 - 3 } & Post-test & $19.45+7,980$ & \\
\hline
\end{tabular}

*Wilcoxon

The results of the effectiveness of tooth brushing skills before and after treatment showed that the p-value was $0.001(p<0.05)$ meaning that counseling with a tooth brushing demonstration method effectively improved the brushing skills of early childhood teeth in school and the status of dental and oral hygiene status p-value is $0.001(p<0.05)$ meaning that counseling with a brushing demonstration method is effective in reducing the status of dental and oral hygiene in early childhood.

\section{Discussion}

The results of the study of dental and oral hygiene status before counseling with the demonstration method of brushing teeth obtained an average value of dental and oral hygiene status of 31.95 including the medium category. In line with Pantow research (2014), the mean plaque index value before counseling using the brushing demonstration method was 1.53 in the medium category.

This is because early childhood children do not yet have the ability to brush their teeth properly proven the average value of children's tooth brushing skills of 5.67, including the category of less skilled, so that it affects the cleanliness of teeth and mouth. Strengthened Arianto et al (2014), states that brushing their teeth properly and correctly can affect the status of dental and oral hygiene. ${ }^{7,14}$

Then the respondent is given an intervention, the first step is to introduce the tooth brushing equipment along with the storage area stored in the school environment. The response of the sample in initiating more enthusiasm and enthusiasm, means that the stimulus given to the child was successfully seen by the child's ability to retrieve and store it easily. Purnama (2019) states that the provision of school toothbrush storage model facilities in the form of toothbrushes and toothpaste and gargle glasses in person so that children find it easier to take and store toothbrushes without the help of others. ${ }^{8}$

Researchers conducted counseling and demonstrations to brush their teeth using phantom media. For children, how to brush teeth need to be given an example of a good model and with the simplest technique possible. Delivery of dental and oral health education to children must be made as attractive as possible, including through attractive counseling without reducing the content of education, demonstrations directly. The choice of demonstration method in oral and dental health education supports the improvement of children's understanding, by directly practicing the right way to brush their teeth. ${ }^{6}$ Furthermore, respondents do tooth brushing exercises every day for 5 consecutive days, this is in line with Research Pujiyasari (2015) the method of brushing teeth for 4 times can increase the independence of brushing your teeth. Makuch (2011) statement is also reinforced that the method of brushing teeth can be applied to teach preschoolers' brushing skills. ${ }^{15,16}$

The results of the effectiveness test of tooth brushing skills and after being treated showed that the p-value was $0.001(p<0.05)$ meaning that counseling with a tooth brushing demonstration method was effective in improving brushing skills in early childhood at school. This also justifies the opinion expressed by Ilyas (2012) demonstration method on oral health counseling to support increased understanding of children, by practicing directly how to brush teeth correctly. ${ }^{6}$

This success was also seen in the improvement of the child's dental and oral hygiene status. The results of the effectiveness test of oral and dental hygiene status and after being treated showed that the p-value was $0.001(\mathrm{p}<0.05)$ meaning that counseling with a tooth brushing demonstration method effectively improved the status of dental and oral hygiene in early childhood at school. The dental and mouth hygiene status scores decreased because they were given treatment in the form of counseling using a demonstration method about oral health, especially how to brush teeth correctly so that with this counseling, students will increase their knowledge so they are able to practice the right teeth brushing. The practice of brushing your teeth 
properly will be able to remove plaque. Purnama et al (2019), proving that brushing your teeth with the right techniques will improve your brushing skills and clean teeth and mouth. Ilyas (2012) also proved the promotion of dental and oral health with a demonstration method for decreasing dental and oral hygiene scores. ${ }^{6,8}$

\section{Conclusion}

\section{Based on the results of the study, it can be concluded that:}

1. Counseling with demonstration method proved significantly $(p<0.001)$ effectively improve early childhood toothbrushing skills in school.

2. Counseling with demonstration method proved significantly $(p<0.001)$ effectively improve the status of dental hygiene in early childhood

Source Funding: This study was done by selffunding from the authors.

Conflict of Interest: The authors declare that they have no conflict interests.

Ethical Clearance: All participants were signed the informed consent prior to the data collection.

\section{Reference}

1 Ministry of Health. School Dental Health Business Guidelines (UKGS). Jakarta, Directorate General of Health Efforts; 2012.

2 Ministry of Health. National Action Plan for Dental and Oral Health Services 2015-2019. Jakarta, Directorate General of Health Efforts; 2015.

3 Alhamda S. Status of dental and oral hygiene with dental caries status (study of 12-year-old students in the Bukittinggi city state elementary school). Journal of Community Medicine News. 2011; 27 (2): 108 .

4 Purnama T, Rasipin R, Ngatemi. Tedi's Behavior Change Model to Improving Brushing Teeth Behavior Parents. Journal of Applied Health Management Technology. 2020; 2 (1): 1-12.

5 Ministry of Health. Main results Riskesdas 2018. Research and Development Agency; 2018. p.179217

6 Ilyas M, Putri I. The effect of counseling on the demonstration method of brushing teeth on decreasing the dental plaque index in elementary school students. Dentofacial Journal of Dentistry. 2012; 11 (2): 91-95.

7 Arianto A, Shaluhiyah Z, Nugraha P. Teeth Brushing Behavior in Elementary School Students Class V and VI in Sumberejo District. Indonesian Health Promotion Journal. 2014; 9 (2): 127-135.

8 Purnama T, Rasipin R, Santoso B. Effects of Tedi's Behavior Change Model Training on Teachers and Parents on the Teeth Brush Skills of Preschoolers. Journal Health Quality. 2019; 13 (2): 75-81.

9 Yuliana NM, Setiawan H, Hendari R. Effect of Education Through Dental Care to Clean Dental and Mouth Patients in Post-Dental Patients Due to Caries. Journal of Dental Health. 2014; 2 (2): 249259.

10 Zulfikri Z, Huda Z. The Relationship of the Dental and Mouth Clean Index With The Dental Career Index In The Disciples of SDN 03 Features of Kurai Subdistrict, Long Guguk District, Bukittinggi City. Journal of Dental Health. 2017; 4 (1): 55-62.

11 Prasko P, Santoso B, Sutomo B. Counseling of audio visual method and demonstration of the knowledge of brushing teeth in elementary school children. Journal of Dental Health. 2016; 3 (2): 5357.

12 Agustin D. The Use of Demonstration Method Against Ability to Brush Teeth in Children with ADHD (Attention Deficit Hyperactivity Disorder). Special Education Journal. 2014; 6 (6).

13 Ngatemi, Purnama T. Dental Health Handbook as Parents Monitoring in the Formation of Independence for Brushing Teeth in Early Childhood. Indian Journal of Public Health Research Development. 2020; 11(1):785-790

14 Pantow CB, Warouw SM, Gunawan PN. The Effect of Counseling on Brushing Teeth Against Dental Plaque Index on Elementary Inpres Field Students. Journal e-Gigi 2014; 2 (2).

15 Pujiyasari S, Asih SHM, Nurullita U. The effect of brushing teeth training method on the independence of brushing children's teeth in school-age mental retardation. Journal of Nursing and Midwifery. 2014; 3:1-11

16 Makuch A, Reschke K, Rupf S. Effective teaching of tooth-brushing to preschool children. J Dent Child (Chic). 2011; 78 (1): 9-12. 